\title{
A Cross-cultural Comparative Study of Uses and Perceptions of Technology in Education among Turkish and US Undergraduates
}

\author{
Erkan Tekinarslan ${ }^{1}$, Eugene Kennedy ${ }^{2}$, Pamela S. Nicolle ${ }^{3}$ \\ ${ }^{1}$ Faculty of Education, Abant Izzet Baysal University, Turkey \\ ${ }^{2}$ School of Education, Louisiana State University, USA \\ ${ }^{3}$ Information Technology Services, Louisiana State University, USA \\ Correspondence: Erkan Tekinarslan, Faculty of Education, No: 325, Abant Izzet Baysal University, Gölköy Campus, \\ 14280 Bolu, Turkey
}

Received: July 29, 2015 Accepted: August 17, 2015 Online Published: August 27, 2015

doi:10.11114/jets.v3i6.1055 URL: http://dx.doi.org/10.11114/jets.v3i6.1055

\begin{abstract}
The purpose of this study was to investigate differences and similarities among United States (US) and Turkish university students in technology ownership, uses of technology for academic purposes, perceived importance of technology, and preferences for technology in education. The EDUCAUSE Center for Analytics and Research (ECAR) undergraduate student technology survey was used to collect data from Turkish students $(\mathrm{N}=384)$ at Abant Izzet Baysal University and US students (N=399) at Louisiana State University (LSU). The findings revealed significant differences in uses and ownership of most technological devices in favor of the US students in comparison to the Turkish students. The results of the study pointed to differences in information technology (IT) ownership and access, largely as a function of local infrastructure and economic settings rather than cultural diversities between Turkey and the US.
\end{abstract}

Keywords: Turkish and US undergraduate students, educational technology use, perceived importance of technology, device ownership, uses of mobile devices, preferences for form of instructor communication

\section{Introduction}

Technology is an ever growing part of the contemporary landscape, often redefining the ways in which everyday activities are done and tearing down national and even cultural boundaries. In education, for example, students in the United States (US) routinely interact with young people in other parts of the world. These interactions occur in structured classroom settings and also in less formal ways. Geographic boundaries for younger generations are increasingly less restrictive than was true for older generations. Contemporary students are exposed to ideas, form friendships and interact with other young people in disparate parts of the planet on an almost daily basis. In the past, norms regarding technology use patterns were believed to be, in a large part, determined by the cultural milieu in which students lived, but among younger generations it is potentially the case that technology adoption and use patterns are increasingly taking on a global uniformity. This comparative study contrasts a Western society characterized by cultural norms punctuated by individualism and autonomy with a Mid-Eastern society characterized by collectivism and conformity (Ayçiçegi-Dinn \& Caldwell-Harris, 2011). Specifically, the study focuses on technology access, use, perceptions and desires among undergraduate students enrolled at research extensive universities in the two different societies.

\subsection{Generational and Cultural Differences in Technology Use}

Who uses technology and why has it been the focus of considerable research for much of the past several decades? Theories on technology adoption in educational settings have proliferated and increasingly, researchers have noted generational differences, with younger generations of students often having greater technology sophistication than their older teachers. Similarly, differences in access to technology, use of technology for educational, entertainment or social purposes have often focused on gender differences, differences among various social classes of students, and differences among culturally distinct subgroups. These lines of inquiry have grown even more significant as mobile devices have proliferated in nearly every society. In education, younger generations continue to be more adaptive and engaged with mobile learning than is true of older generations. In fact, each cohort seems to push the technology frontier further than 
their predecessor. In many societies, most teenagers intensively use digital technology, especially the Internet. Also, this generation has been given many names that emphasize its affinity and tendency to use digital technology, such as "digital natives" or the "net generation" (Prensky, 2001, cited in Kolikant, 2010), and the Net Generation (Oliver \& Goerke, 2007; Tapscott, 1998, cited in Kolikant, 2010).

The devices likely to be found in the "digital backpack" of the Net Generation are changing rapidly (Oliver \& Goerke, 2007). For instance, mobile phones began as voice communication tools and rapidly became devices for text and image exchange. The more sophisticated "smart" phone had basic office software capabilities, wireless connection, greater Internet capability, and a host of basic computing functions, as well as thumb and extendable keyboards (Trinder, 2005, cited in Oliver \& Goerke, 2007 ). Particularly, the related literature and studies in developed countries such as the US and Australia suggest that current undergraduates, part of the so called Net Generation, are high end users of emerging technologies such as mobile devices and new communication tools (Oliver \& Goerke, 2007; Kolikant, 2010 ).

Several researchers have reported differences in attitudes and perceptions of technology among people in different cultures (Singh, Fassott, Chao \& Hoffmann, 2006; Haris \& Davison, 2002; Blignaut, McDonald \& Tolmie, 2002; Durndell, Haag, \& Laithwaite, 2000). Other studies conducted in educational environments (Teo, Su Luan, \& Sing, 2008; McCoy, Galletta, \& King, 2007; Li \& Kirkup, 2007) also suggest the possibility of differences in attitudes and perceptions of technology among students in different cultures. For example, Li and Kirkup (2007) investigated differences in the use of and attitudes toward the Internet and computers for Chinese $(\mathrm{N}=220)$ and British students $(\mathrm{N}=245)$. They found significant differences in Internet experience, attitudes, usage, and self-confidence between Chinese and British students. Particularly, British students were more likely to use computers for study purposes than Chinese students, but Chinese students were more self-confident about their advanced computer skills. In addition, in a study, conducted by Durndell, Haag and Laithwaite (2000), computer self-efficacy of Romanian (N=200) and Scottish students (148) were compared. In general, males were more confident than females in advanced file and software computer skills, but of similar confidence for beginning skills. Scottish males and females were more confident than their Romanian counterparts for beginning computer skills, while Romanian students were more confident in advanced computer skills.

The current study explores the centrality of the role of technology in education or academic environments among different cohorts of students and students in two significantly different cultural contexts. In particular, this study investigates differences and similarities between United States (US) students at Louisiana State University (LSU) and Turkish students at Abant Izzet Baysal University (AIBU) in device ownership, perceptions of the value of technology to education in terms of uses of technology for academic course work, and perceived importance of technology to academic success.

\subsection{Profiles of Countries and Universities}

United States of America (US): The United States of America (USA), commonly referred to as the United States (U.S.), is a federal republic consisting of 50 states and a federal district. The US is a developed country with an approximate three hundred twenty million population $(\mathrm{n}=32020600)$ and $\$ 53$ thousand GDP per capita (Wikipedia, 2015a). The US is one of the world leaders in technology development, access and infrastructure (OECD, 2014). In most US universities technology is widely available and integrated into many classrooms (Indalytics, 2013). Faculty and students are likely to own several devices and to use them for a range of social and educational purposes. The US is also a multicultural society, characterized by a priority placed on individual autonomy, self-effort and an underlying non-conformist character (Ayçiçegi-Dinn \& Caldwell-Harris, 2011). As such, there are few cultural restrictions placed on technology use and access. Nevertheless, differences persist among segments of the population.

Turkey: Turkey is a parliamentary republic largely located in Western Asia with the portion of Eastern Thrace in Southeastern Europe. Turkey, founded as a republic in 1923 following the downfall of the Ottomans, is a fast developing country with an approximate seventy seven million population $(\mathrm{n}=77695904)$ and $\$ 11$ thousand GDP per capita (Wikipedia, 2015b). The constitution in Turkey governs the legal framework of the country. It sets out the main principles of government and establishes Turkey as a unitary centralized state (Wikipedia, 2015b). The Turkish Republic is a society characterized by more collectivism in comparison to US society (Ayçiçegi-Dinn \& Caldwell-Harris, 2011). Conformity is a highly valued aspect of the Turkish character (Kağıtçıbaşı, 2007, cited in Delevi \& Bugay, 2010) and working toward the collective good rivals the prominence of individualism in the US. Turkey has a growing technology infrastructure with increasing technology access for its population (OECD, 2014). Mobile phone use among younger generations in Turkey rivals that of any industrialized country (Wikipedia, 2014; Hurriyetdailynews.com, 2015; Budde.com.au, 2015).

As a result, both the level of technological development and the basic underpinnings of the two societies point to potential differences in technology access, attitudes and use among the populations. This particular study focuses on 
younger generations, particularly undergraduates enrolled at research extensive universities.

\subsection{The Universities Studied}

Louisiana State University ( $L S U)$ : LSU, founded in 1853, is a public coeducational university located in Baton Rouge, Louisiana, US. The University enrolls nearly 29,000 students in 14 schools and colleges. There are about 1500 academic staff at LSU (Wikipedia, 2015c).

Abant Izzet Baysal University (AIBU): AIBU, founded in 1992, is a foundation supported state university in Bolu, Turkey. There are nearly 20,000 students in 21 schools and colleges within AIBU. The university employs about 900 academic staff (Wikipedia, 2015d).

\subsection{Purpose of the Study}

The purpose of the study is to investigate uses and perceptions of the value of technology in education or academic environments among different cohorts of students in two significantly different cultural contexts. Specifically, using data from the 2013 administration of the EDUCAUSE Center for Analytics and Research (ECAR) student technology survey, this study investigates differences and similarities between US students at LSU and Turkish students at AIBU in terms of technological device ownership, uses of technology for academic course work, and perceived importance of technology to academic success. In addition, differences and similarities in device ownership and uses by gender and year (freshmen, sophomore, junior, senior) are examined.

\subsection{Research Questions}

1. Is there any gender difference in device ownership (i.e., laptop computer, desktop computer, tablet computer, smartphone and e-reader) of the US students at LSU and Turkish students at AIBU?

2. Is there any difference between US students at LSU and Turkish students at AIBU in ownership of technological devices (i.e., laptop computer, desktop computer, tablet computer, smartphone and e-reader) by year (i.e., freshmen, sophomore, junior, senior)?

3. Is there any difference between US students at LSU and Turkish students in terms of importance of resources and tools (i.e., academic institution's library Web site, course or learning management system, Web-based citation/bibliography tools, university Web site, e-portfolios, e-books, freely available course content beyond campus, simulations or educational tools) to academic success?

4. Is there any difference between US male and Turkish male students and US female and Turkish female students in terms of importance of resources and tools (academic institution's library Web site, course or learning management system, , Web-based citation/bibliography tools, university Web site, e-portfolios, e-books, freely available course content beyond campus, simulations or educational tools) to academic success?

5. Is there any difference between US and Turkish students in use of technology (i.e., course content from the Internet, e-portfolios, e-books, simulations and games) for academic course work?

6. Is there any difference between US and Turkish male students in uses of technology (i.e., course content from the Internet, e-portfolios, e-books, simulations and games) for academic course work?

7. Is there any difference between US and Turkish female students in uses of technology (i.e., course content from the Internet, e-portfolios, e-books, simulations and games) for academic course work?

8. Is there any difference between US and Turkish students in their perceptions of the Institution's support of activities (i.e., accessing library resources, checking grades registering for courses, accessing financial aid, ordering transcripts, using LMS such as Moodle and Blackboard, accessing information about events, student scheduling appointments) from a mobile device?

9. Is there any difference between US and Turkish students in their perceptions of instructor use of technology?

10. Is there any difference between US students at LSU and Turkish students at AIBU in terms of importance of getting training in use of technology?

11. Is there any difference between US and Turkish students in terms of preferences for forms of instructor's communication?

\section{Methods}

\subsection{Participants}

As indicated in Table 1, 399 United States (US) students (41.6\% male, 57\% female) from Louisiana State University (LSU), and 384 Turkish students (35.4\% male, 62.8\% female) from Abant Izzet Baysal University (AIBU) participated in the study. The majority of respondents are female for both universities. The percentages of freshmen, juniors, and seniors are similar for both campuses. But, the percentage of sophomores in the Turkish AIBU sample is nearly twice that of the US LSU sample. In addition, the percentages of part and full-time students are close to each other. In 
addition, the majority of students in both campuses fall within the 18-24 age range.

Table 1. Demographics of US and Turkish Students

\begin{tabular}{|c|c|c|c|}
\hline & & $\begin{array}{c}\text { LSU } \\
(\mathrm{n}=399)\end{array}$ & $\begin{array}{c}\text { AIBU } \\
(\mathrm{n}=384)\end{array}$ \\
\hline \multirow[t]{4}{*}{ Gender } & Male & $41.6 \%(n=166)$ & $35.4 \%(\mathrm{n}=136)$ \\
\hline & Female & $57.0 \%(\mathrm{n}=227)$ & $62.8 \%(\mathrm{n}=241)$ \\
\hline & No answer & $1,4 \%(n=6)$ & $1,8 \%(\mathrm{n}=7)$ \\
\hline & Freshman & $18.0 \%(n=72)$ & $15.9 \%(n=61)$ \\
\hline \multirow[t]{4}{*}{ Year } & Sophomore & $23.3 \%(n=93)$ & $43.0 \%(n=165)$ \\
\hline & Junior & $26.6 \%(n=106)$ & $22.4 \%(\mathrm{n}=86)$ \\
\hline & Senior & $27.3 \%(n=109)$ & $14,6 \%(n=56)$ \\
\hline & Other & $4,8 \%(n=19)$ & $4,2 \%(\mathrm{n}=16)$ \\
\hline \multirow[t]{2}{*}{ Status } & Full-Time & $91.9 \%(\mathrm{n}=367)$ & $88.7 \%(n=341)$ \\
\hline & Part -Time & $8.2 \%(\mathrm{n}=32)$ & $11.3 \%(\mathrm{n}=43)$ \\
\hline \multirow[t]{2}{*}{ Age } & $18-24$ & $91.7 \%(n=366)$ & $98.4 \%(n=378)$ \\
\hline & $25+$ & $8.3 \%(n=33)$ & $1.6 \%(\mathrm{n}=6)$ \\
\hline
\end{tabular}

\subsection{Research Instrument}

The EDUCAUSE Center for Analytics and Research (ECAR) (2013) undergraduate student technology survey was used to collect data from Turkish students (N=384) at Abant Izzet Baysal University and United States (US) students (N=399) at Louisiana State University (LSU). The ECAR survey consists of six sections (i.e., About You, Device Use and Ownership, Technology and the College Experience, Learning Environments, Your Personal Computing Environment, Demographic and Informational Questions) which takes about 20 minutes to answer or fill out. A translated Turkish version of the ECAR survey was used to collect data from Turkish students. The ECAR survey in Turkish was translated into Turkish by one of the authors who is proficient in both Turkish and English. The translation of the survey in Turkish was validated by another academician who is also proficient in both English and Turkish, as well. Before collecting the data, the survey in Turkish was applied to a group of students $(n=45)$ in a pilot study to test whether the students understood the items in the survey or not. A large majority of students $(n=39)$ did not have any difficulty understanding most of the items. However, six students did not understand the translation of some words in Turkish (e.g., simulations, online, tablet) since many times they are used as they are in English. Thus, the meanings of these words in English were typed in parentheses after their meaning in Turkish. An online version of the ECAR survey was used to the collect data from US students at LSU, but the Turkish students filled out a paper based version of the survey in their classes on a voluntary basis.

\subsection{Data analysis}

The SPSS statistical package program was used to analyze the data using descriptive statistics, Mann-Whitney U test, Chi-square test and cross-tabulations. The significance level was taken as .05 in the related analyses.

\section{Results}

\subsection{Device Ownership by Gender}

As displayed in Table 2, Pearson chi-square test results (X2) regarding technology ownership by gender indicated that a significantly higher percentage of US male students at LSU (95.8\%) have laptop computers than the Turkish male students at AIBU $(72.5 \%)(\mathrm{X} 2=32.43, \mathrm{p}=0.00)$. Furthermore, a significantly greater percentage of US male students at LSU (88\%) have smartphones than the Turkish male students at AIBU $(60.3 \%)(\mathrm{X} 2=35.18, \mathrm{p}=0.00)$. However, a significantly greater percentage of Turkish male students at AIBU (52.2\%) report desktop PC ownership than the US male students at LSU $(28.3 \%)(\mathrm{X} 2=21.61, \mathrm{p}=0.00)$. On the other hand, there is no significant difference in tablet computer ownership between of US male students at LSU (29.5\%) and the Turkish male students at AIBU (24.6\%) $(\mathrm{X} 2=9.66, \mathrm{p}=0.08)$. Also, there is no difference in e-reader ownership between US male $(14.5 \%)$ and Turkish male students $(12.6 \%)(\mathrm{X} 2=.660, \mathrm{p}=0.719)$.

Table 2. Device Ownership by Gender

\begin{tabular}{|c|c|c|c|c|c|c|c|c|}
\hline & \multicolumn{2}{|c|}{ US and Turkish Male } & \multicolumn{2}{|c|}{ US and Turkish Female } & \multicolumn{2}{|c|}{$\begin{array}{l}\text { US Male and Turkish } \\
\text { Female }\end{array}$} & \multicolumn{2}{|c|}{$\begin{array}{l}\text { US Female and Turkish } \\
\text { Male }\end{array}$} \\
\hline & LSU (US) & $\begin{array}{c}\text { AIBU } \\
\text { (Turkish) }\end{array}$ & LSU (US) & $\begin{array}{c}\text { AIBU } \\
\text { (Turkish) }\end{array}$ & $\begin{array}{l}\text { LSU Male } \\
\text { (US) }\end{array}$ & $\begin{array}{l}\text { AIBU Female } \\
\text { (Turkish) }\end{array}$ & $\begin{array}{l}\text { LSU } \\
\text { (US) }\end{array}$ & $\begin{array}{c}\text { AIBU } \\
\text { (Turkish) }\end{array}$ \\
\hline Device & $(n=166)$ & $(n=136)$ & $(n=227)$ & $(n=241)$ & $(n=166)$ & $(n=241)$ & $(n=227)$ & $(n=136)$ \\
\hline Laptop & $95.8 \%{ }^{*}$ & $72.5 \%^{*}$ & $99.1 \%{ }^{*}$ & $85.5 \%^{*}$ & $95.8 \%^{*}$ & $85.5 \%{ }^{*}$ & $99.1 \%{ }^{*}$ & $72.5 \%^{*}$ \\
\hline Tablet & $29.5 \%$ & $24.6 \%$ & $25.1 \%^{*}$ & $13.4 \%^{*}$ & $29.5 \%^{*}$ & $13.4 \%{ }^{*}$ & $25.1 \%$ & $24.6 \%$ \\
\hline Smartphone & $88 \%^{*}$ & $60.3 \%^{*}$ & $90.7 \%^{*}$ & $57.7 \%^{*}$ & $88 \%^{*}$ & $57.7 \%^{*}$ & $90.7 \%^{*}$ & $60.3 \%^{*}$ \\
\hline Desktop PC & $28.3 \%^{*}$ & $52.2 \%^{*}$ & $19.8 \%^{*}$ & $40.7 \%^{*}$ & $28.3 \%^{*}$ & $40.7 \%{ }^{*}$ & $19.8 \%^{*}$ & $52.2 \%^{*}$ \\
\hline
\end{tabular}

Significant at the .05 level. 
Additionally, Pearson chi-square test results (X2) indicated that a significantly greater percentage of US female students at LSU (99.1\%) have laptop computers than the Turkish female students at AIBU (85.5\%) (X2=29.92, $\mathrm{p}=0.00)$. Moreover, a significantly greater percentage of US female students at LSU (25.1\%) report tablet computer ownership than the Turkish female students at AIBU (13.4\%) $(\mathrm{X} 2=23.39, \mathrm{p}=0.00)$. In addition, a significantly greater percentage of US female students at LSU (90.7\%) have smartphones than the Turkish female students at AIBU $(57.7 \%)(X 2=69.06$, $\mathrm{p}=0.00$ ). Similarly, a significantly higher percentage of US female students at LSU (20.7\%) report e-reader ownership than the Turkish female students at AIBU (4.6\%) $(\mathrm{X} 2=34.15, \mathrm{p}=0.00)$. However, similar to the difference between US male and Turkish male students, a significantly greater percentage of Turkish female students at AIBU (40.7\%) have desktop PC's than the US female students at LSU $(19.8 \%)(\mathrm{X} 2=25.68, \mathrm{p}=0.00)$.

Moreover, Pearson chi-square test results (X2) showed that a significantly greater percentage of US male students at LSU (95.8\%) report laptop computers ownership than the Turkish female students at AIBU (85.5\%) (X2=11.31, $\mathrm{p}=0.03$ ). Similarly, a significantly greater percentage of US male students at LSU (29.5\%) report tablet computer ownership than the Turkish female students at $\operatorname{AIBU}(13.4 \%)(\mathrm{X} 2=23.94, \mathrm{p}=0.00)$. Furthermore, a significantly greater percentage of US male students at LSU (88\%) have smartphones than the Turkish female students at AIBU (57.7\%) $(\mathrm{X} 2=49.60, \mathrm{p}=0.00)$. Additionally, a significantly greater percentage of US male students at LSU (14.5\%) report e-reader ownership than the Turkish female students at AIBU (4.6\%) $(\mathrm{X} 2=11.86, \mathrm{p}=0.03)$. However, a significantly greater percentage of Turkish female students at AIBU (40.7\%) report desktop PC ownership than the US male students at $\operatorname{LSU}(28.3 \%)(\mathrm{X} 2=19.03, \mathrm{p}=0.00)$.

In addition, Pearson chi-square test results (X2) indicated that a significantly greater percentage of US female students at LSU (99.1\%) have laptop computers than the Turkish male students at AIBU (72.5\%) (X2=62.13, p=0.00). Furthermore, a significantly greater percentage of US female students at LSU (90.7\%) have smartphones than the Turkish male students at AIBU $(60.3 \%)(\mathrm{X} 2=49.74, \mathrm{p}=0.00)$. Also, a higher percentage of US female students at LSU (20.7\%) report e-reader ownership than the Turkish male students at AIBU (12.6\%) at 0.05 significance level $(\mathrm{X} 2=$ 5.90). However, similar to the difference between US male and Turkish male students, a significantly greater percentage of Turkish male students at AIBU (52.2\%) have desktop PC's than the US female students at LSU (19.8\%) (X2=41.08, $\mathrm{p}=0.00$ ). On the other hand, there is no significant difference in tablet computer ownership between US female students at LSU (25.1\%) and Turkish male students at AIBU (24.6\%).

\subsection{Device Ownership by School Level}

As indicated in Table 3, laptop ownership is the highest for all levels at both universities, followed by smartphone ownership. However, e-reader ownership is the lowest for all levels at both universities. With the exception of desktops, a greater percentage of US students at LSU report technology ownership than the Turkish students at similar levels at AIBU. In most instances, these differences are statistically significant.

Table 3. Device Ownership of the US and Turkish Students

\begin{tabular}{lcccccccc}
\hline & \multicolumn{2}{c}{ Freshmen } & \multicolumn{2}{c}{ Sophomores } & \multicolumn{2}{c}{ Juniors } & \multicolumn{2}{c}{ Seniors } \\
& LSU & AIBU & LSU & AIBU & LSU & AIBU & LSU & AIBU \\
$(\mathrm{n}=72)$ & $(\mathrm{n}=61)$ & $(\mathrm{n}=93)$ & $(\mathrm{n}=165)$ & $(\mathrm{n}=106)$ & $(\mathrm{n}=86)$ & $(\mathrm{n}=109)$ & $(\mathrm{n}=56)$ \\
\hline Laptop & $100 \%^{*}$ & $78.3 \%^{*}$ & $97.8 \%^{*}$ & $81.9 \%^{*}$ & $98.1 \%$ & $95.1 \%$ & $97.2 \%^{*}$ & $88.9 \%^{*}$ \\
Tablet & $54.2 \%^{*}$ & $27.9 \%^{*}$ & $36.6 \%^{*}$ & $22.7 \%^{*}$ & $34.9 \%$ & $21.7 \%^{*}$ & $42.2 \%^{*}$ & $21.8 \%^{*}$ \\
Smartphone & $93.1 \%^{*}$ & $70.5^{*}$ & $93.5 \%^{*}$ & $63.6 \%^{*}$ & $92.5 \%^{*}$ & $57.0 \%^{*}$ & $95.4 \%^{*}$ & $67.9 \%^{*}$ \\
e-Reader & $16.7 \%$ & $15.0 \%$ & $21.5 \%^{*}$ & $9.8 \%^{*}$ & $19.8 \%^{*}$ & $6.0 \%^{*}$ & $23.9 \%$ & $5.5 \%$ \\
Desktop PC & $23.6 \%^{*}$ & $52.5 \%^{*}$ & $28.0 \%^{*}$ & $47.9 \%^{*}$ & $27.4 \%^{*}$ & $43.0 \%^{*}$ & $30.3 \%$ & $42.9 \%$ \\
\hline
\end{tabular}

* Significant at the .05 level.

\subsection{Perceived Importance to Academic Success}

Mann-Whitney-U test results in Table 4 concerning the importance of resources and tools to academic success indicated that, while course or learning management systems (LMSs), Web-based bibliography tools, and freely available course content beyond their campus are more important for the US students at LSU, academic institution's library website, e-portfolios, e-books, and simulations or educational games are more important for the Turkish students at AIBU. There is no difference in importance of a college or university web site to achieve academic success between the US and Turkish students. 
Table 4. Importance of Resources and Tools to Academic Success

\begin{tabular}{|c|c|c|}
\hline $\begin{array}{l}\text { How important are the following resources/tools to achieving your academic } \\
\text { success? }\end{array}$ & $\begin{array}{c}\text { LSU } \\
\text { (Mean Rank) } \\
\end{array}$ & $\begin{array}{c}\text { AIBU } \\
\text { (Mean Rank) } \\
\end{array}$ \\
\hline Academic Institution's Library Website & $\begin{array}{l}355.67^{*} \\
(\mathrm{n}=397)\end{array}$ & $\begin{array}{c}426.6^{*} \\
(n=383)\end{array}$ \\
\hline Course or Learning Management System (LMS) & $\begin{array}{l}515.36^{*} \\
(\mathrm{n}=391)\end{array}$ & $\begin{array}{l}260.36^{*} \\
(\mathrm{n}=384)\end{array}$ \\
\hline Web-based Bibliography Tools & $\begin{array}{l}409.33^{*} \\
(\mathrm{n}=393)\end{array}$ & $\begin{array}{l}367.13^{*} \\
(\mathrm{n}=383)\end{array}$ \\
\hline College/University Website & $\begin{array}{l}401.92 \\
(n=396)\end{array}$ & $\begin{array}{c}378.72 \\
(\mathrm{n}=384)\end{array}$ \\
\hline E-portfolios & $\begin{array}{l}335.86^{*} \\
(\mathrm{n}=390)\end{array}$ & $\begin{array}{l}436.45^{*} \\
(\mathrm{n}=380)\end{array}$ \\
\hline E-books & $\begin{array}{l}370.88^{*} \\
(\mathrm{n}=393)\end{array}$ & $\begin{array}{l}407.54^{*} \\
(\mathrm{n}=384)\end{array}$ \\
\hline Freely Available Course Content Beyond Your Campus & $\begin{array}{l}397.18^{*} \\
(\mathrm{n}=393)\end{array}$ & $\begin{array}{l}377.52^{*} \\
(\mathrm{n}=381)\end{array}$ \\
\hline Simulations or Educational Games & $\begin{array}{l}353.89^{*} \\
(\mathrm{n}=398)\end{array}$ & $\begin{array}{l}428.64^{*} \\
(n=382)\end{array}$ \\
\hline
\end{tabular}

"Mean ranks are statistically significant at the .05 level.

\subsection{Perceived Importance to Academic Success by US and Turkish Male Students}

According to the Mann-Whitney-U test results in Table 5 about the importance of resources and tools to academic success, LMSs are more important for the US male students at LSU in comparison to the Turkish male students at AIBU. However, academic institution's library website, e-portfolios, and simulations or educational games are more important for the Turkish male students at AIBU in comparison to the US male students at LSU. There is no difference in importance of Web-based bibliography tools, college or university web site, e-Books, and freely available course content beyond campus to achieve academic success between the US male and Turkish male students.

Table 5. Importance of Resources and Tools to Academic Success by US and Turkish Male Students

\begin{tabular}{|c|c|c|}
\hline $\begin{array}{l}\text { How important are the following resources/tools to achieving your } \\
\text { academic success? }\end{array}$ & $\begin{array}{l}\text { US Male at LSU } \\
\text { (Mean Rank) }\end{array}$ & $\begin{array}{l}\text { Turkish Male AIBU } \\
\text { (Mean Rank) }\end{array}$ \\
\hline Academic Institution's Library Website & $\begin{array}{l}137.34^{*} \\
(\mathrm{n}=165)\end{array}$ & $\begin{array}{l}166.59^{*} \\
(\mathrm{n}=135)\end{array}$ \\
\hline Course or Learning Management System (LMS) & $\begin{array}{l}186.21^{*} \\
(\mathrm{n}=164)\end{array}$ & $\begin{array}{l}107.44^{*} \\
(\mathrm{n}=136)\end{array}$ \\
\hline Web-based Bibliography Tools & $\begin{array}{c}150.95 \\
(\mathrm{n}=165)\end{array}$ & $\begin{array}{c}151.07 \\
(\mathrm{n}=136)\end{array}$ \\
\hline College/University Website & $\begin{array}{c}150.24 \\
(\mathrm{n}=165)\end{array}$ & $\begin{array}{c}151.22 \\
(\mathrm{n}=136)\end{array}$ \\
\hline E-portfolios & $\begin{array}{l}128.02^{*} \\
(\mathrm{n}=162)\end{array}$ & $\begin{array}{l}172.34^{*} \\
(\mathrm{n}=133)\end{array}$ \\
\hline E-Books & $\begin{array}{l}142.75 \\
(\mathrm{n}=163)\end{array}$ & $\begin{array}{l}158.68 \\
(\mathrm{n}=136)\end{array}$ \\
\hline Freely Available Course Content Beyond Your Campus & $\begin{array}{l}153.94 \\
(\mathrm{n}=163)\end{array}$ & $\begin{array}{l}145.28 \\
(\mathrm{n}=136)\end{array}$ \\
\hline Simulations or Educational Games & $\begin{array}{l}137.25^{*} \\
(\mathrm{n}=165)\end{array}$ & $\begin{array}{l}167.68^{*} \\
(\mathrm{n}=136)\end{array}$ \\
\hline
\end{tabular}

*Mean ranks are statistically significant at the .05 level.

\subsection{Perceived Importance to Academic Success by US and Turkish Female Students}

Mann-Whitney-U test results in Table 6 about the importance of resources and tools to academic success indicated that LMSs, Web-based Bibliography Tools, College/University Website are more important for the US female students at LSU in comparison to the Turkish female students at AIBU. However, academic institution's library website, e-portfolios, and simulations or educational games are more important for the Turkish female students at AIBU in comparison to the US female students at LSU, similar to the comparison between US male and Turkish male students. There is no difference in importance of e-Books, and freely available course content beyond campus to achieve academic success between the US female and Turkish female students. 
Table 6. Importance of Resources and Tools to Academic Success by US and Turkish Female Students

\begin{tabular}{lcc}
\hline $\begin{array}{l}\text { How important are the following resources/tools to achieving } \\
\text { your academic success? }\end{array}$ & $\begin{array}{c}\text { US Female at LSU } \\
\text { (Mean Rank) }\end{array}$ & $\begin{array}{c}\text { Turkish Female at AIBU } \\
\text { (Mean Rank) }\end{array}$ \\
\hline Academic Institution's Library Website & $214.70^{*}(\mathrm{n}=226)$ & $252.10^{*}(\mathrm{n}=241)$ \\
Course or Learning Management System (LMS) & $319.62^{*}(\mathrm{n}=221)$ & $150.70^{*}(\mathrm{n}=241)$ \\
Web-based Bibliography Tools & $255.26^{*}(\mathrm{n}=224)$ & $211.26^{*}(\mathrm{n}=240)$ \\
College/University Website & $248.91^{*}(\mathrm{n}=225)$ & $219.11^{*}(\mathrm{n}=241)$ \\
E-portfolios & $202.39^{*}(\mathrm{n}=222)$ & $252.43^{*}(\mathrm{n}=240)$ \\
E-Books & $222.37(\mathrm{n}=224)$ & $242.88(\mathrm{n}=241)$ \\
Freely Available Course Content Beyond Your Campus & $237.24^{*}(\mathrm{n}=224)$ & $\left.226.09 \mathrm{~S}^{*} \mathrm{n}=238\right)$ \\
Simulations or Educational Games & $212.42^{*}(\mathrm{n}=227)$ & $253.53^{*}(\mathrm{n}=239)$ \\
\hline
\end{tabular}

*Mean ranks statistically significant at the .05 level.

\subsection{Use of Technology for Academic Course Work}

According to the Mann-Whitney-U test results in Table 7 about use of technology for academic course work, it can be stated that there are significant differences in most items in favor of the US students at LSU by considering the higher mean ranks. Specifically, the US students at LSU used e-portfolios for their academic coursework more commonly than the Turkish students at AIBU did in the past year. In addition, the US students at LSU used e-books for their academic coursework more commonly than the Turkish students at AIBU did in the past year. Similarly, the US students at LSU used simulations and games for their academic coursework more commonly than the Turkish students at AIBU did in the past year. However, the Turkish students at AIBU used course content from the internet for their academic coursework more commonly than the US students at LSU did in the past year.

Table 7. Use of Technology for Academic Course Work

\begin{tabular}{|c|c|c|}
\hline $\begin{array}{l}\text { In the past year, to what extent have you used below } \\
\text { technology/resources for your academic coursework? }\end{array}$ & $\begin{array}{c}\text { LSU } \\
\text { (Mean Rank) }\end{array}$ & $\begin{array}{c}\text { AIBU } \\
\text { (Mean Rank) }\end{array}$ \\
\hline Course content from the internet & $\begin{array}{l}302.81^{*} \\
(\mathrm{n}=281)\end{array}$ & $\begin{array}{l}350.21^{*} \\
(\mathrm{n}=378)\end{array}$ \\
\hline E-portfolios & $\begin{array}{l}276.02^{*} \\
(\mathrm{n}=191)\end{array}$ & $\begin{array}{l}243.22^{*} \\
(\mathrm{n}=319)\end{array}$ \\
\hline E-books & $\begin{array}{l}365.95^{*} \\
(\mathrm{n}=310)\end{array}$ & $\begin{array}{l}239.34^{*} \\
(\mathrm{n}=297)\end{array}$ \\
\hline Simulations and games & $\begin{array}{l}279.57^{*} \\
(\mathrm{n}=263)\end{array}$ & $\begin{array}{l}259.87^{*} \\
(\mathrm{n}=275)\end{array}$ \\
\hline
\end{tabular}

* Mean ranks are statistically significant at the .05 level.

\subsection{Use of Technology for Academic Course Work by US and Turkish Males}

According to the Mann-Whitney-U test results in Table 8 about use of technology for academic course work, there are significant differences in uses of e-books, and simulations and games in favor of the US male students at LSU in comparison to the Turkish male students at AIBU. There is no significant difference between US and Turkish males in uses of course content from the internet, and e-books.

Table 8. Use of Technology for Academic Course Work by US and Turkish Male Students

\begin{tabular}{lcc}
\hline $\begin{array}{l}\text { In the past year, to what extent have you used below } \\
\text { technology /resources for your academic coursework? }\end{array}$ & $\begin{array}{c}\text { US Male at LSU } \\
\text { (Mean Rank) }\end{array}$ & $\begin{array}{c}\text { Turkish Male AIBU } \\
\text { (Mean Rank) }\end{array}$ \\
\hline Course content from the internet & 123.16 & 138.32 \\
& $(\mathrm{n}=126)$ & $95)$ \\
& 103.07 & 95.08 \\
$\mathrm{n}=112)$ \\
E-portfolios & $(\mathrm{n}=84)$ & $90.88^{*}$ \\
& $150.76^{*}$ & $(\mathrm{n}=112)$ \\
E-books & $(\mathrm{n}=134)$ & $96.37^{*}$ \\
Simulations and games & $110.47^{*}$ & $(\mathrm{n}=95)$ \\
\hline
\end{tabular}

* Mean ranks are statistically significant at the .05 level.

\subsection{Use of Technology for Academic Course Work by US and Turkish Females}

Mann-Whitney-U test results in Table 9 about use of technology for academic course work indicate that there are significant differences in uses of e-books, and e-portfolios in favor of the US female students at LSU in comparison to the Turkish female students at AIBU. However, there are significant differences in uses of course content from the Internet in favor of the Turkish female students at AIBU in comparison to the US female students at LSU .There is no significant difference between US and Turkish females in uses of simulations and games. 
Table 9. Use of Technology for Academic Course Work by US and Turkish Female Students

\begin{tabular}{|c|c|c|}
\hline $\begin{array}{l}\text { In the past year, to what extent have you used } \\
\text { technology/resources for your academic coursework? }\end{array}$ & $\begin{array}{l}\text { US Female at LSU } \\
\text { (Mean Rank) }\end{array}$ & $\begin{array}{l}\text { Turkish Female AIBU } \\
\text { (Mean Rank) }\end{array}$ \\
\hline Course content from the internet & $\begin{array}{l}176.11^{*} \\
(\mathrm{n}=153)\end{array}$ & $\begin{array}{l}207.25^{*} \\
(\mathrm{n}=236)\end{array}$ \\
\hline E-portfolios & $\begin{array}{l}169.83^{*} \\
(\mathrm{n}=106)\end{array}$ & $\begin{array}{l}145.65^{*} \\
(\mathrm{n}=201)\end{array}$ \\
\hline E-books & $\begin{array}{l}210.59^{*} \\
(\mathrm{n}=174)\end{array}$ & $\begin{array}{l}145.51^{*} \\
(\mathrm{n}=180)\end{array}$ \\
\hline Simulations and games & $\begin{array}{c}166.56 \\
(n=148)\end{array}$ & $\begin{array}{c}160.02 \\
(\mathrm{n}=177)\end{array}$ \\
\hline
\end{tabular}

*Mean ranks are statistically significant at the .05 level.

\subsection{Institution's Support of Various Activities from a Mobile Device}

According to the Mann-Whitney-U test results in Table 10, by considering the higher mean ranks, it can be stated that US students at LSU have higher ratings than Turkish students at AIBU on all activities from a mobile device. These differences can be explained by the greater percentage of mobile technology (e.g., laptop, tablet, smartphone) ownership of US students at LSU than that of the Turkish students at AIBU as previously displayed in Table 3. Also, it can be stated that LSU has more common services in supporting the activities from a mobile device.

Table 10. Institution's Support of Activities from a Mobile Device

\begin{tabular}{|c|c|c|c|c|c|c|}
\hline \multirow[b]{2}{*}{ Activities } & \multicolumn{2}{|c|}{ Not Offered at the University } & \multicolumn{2}{|c|}{ Haven't Used in the Past Year } & \multicolumn{2}{|c|}{$\begin{array}{c}\text { Rating of University Suppor } \\
\text { (Mean Ranks) }\end{array}$} \\
\hline & $\underset{(n=399)}{\mathrm{LSU}}$ & $\operatorname{AIBU}(\mathrm{n}=384)$ & $\begin{array}{c}\mathrm{LSU} \\
(\mathrm{n}=399)\end{array}$ & $\begin{array}{c}\text { AIBU } \\
(\mathrm{n}=399)\end{array}$ & $\underset{(n=399)}{\operatorname{LSU}}$ & $\begin{array}{l}\text { AIBU } \\
(\mathrm{n}=399)\end{array}$ \\
\hline $\begin{array}{l}\text { Accessing Library } \\
\text { Resources }\end{array}$ & $5.8 \%$ & $4.5 \%$ & $34.9 \%$ & $48.9 \%$ & $\begin{array}{l}240.25^{*} \\
(\mathrm{n}=236)\end{array}$ & $\begin{array}{l}162.67^{*} \\
(\mathrm{n}=177)\end{array}$ \\
\hline Checking Grades & $1.3 \%$ & $2.3 \%$ & $3.5 \%$ & $37.3 \%$ & $\begin{array}{l}332.48^{*} \\
(\mathrm{n}=379)\end{array}$ & $\begin{array}{l}261.23^{*} \\
(\mathrm{n}=231)\end{array}$ \\
\hline $\begin{array}{l}\text { Registering for } \\
\text { Courses }\end{array}$ & $3.6 \%$ & $2.6 \%$ & $18.0 \%$ & $38.7 \%$ & $\begin{array}{l}273.38^{*} \\
(\mathrm{n}=309)\end{array}$ & $\begin{array}{l}256.97^{*} \\
(\mathrm{n}=223)\end{array}$ \\
\hline $\begin{array}{l}\text { Accessing } \\
\text { Financial Aid }\end{array}$ & $2.0 \%$ & $3.7 \%$ & $21.4 \%$ & $52.6 \%$ & $\begin{array}{l}258.06^{*} \\
(\mathrm{n}=304)\end{array}$ & $\begin{array}{l}194.18^{*} \\
(\mathrm{n}=166)\end{array}$ \\
\hline $\begin{array}{l}\text { Ordering } \\
\text { Transcripts }\end{array}$ & $3.0 \%$ & $6.1 \%$ & $33.5 \%$ & $49.5 \%$ & $\begin{array}{l}222.68^{*} \\
(\mathrm{n}=250)\end{array}$ & $\begin{array}{l}191.24^{*} \\
(\mathrm{n}=169)\end{array}$ \\
\hline $\begin{array}{l}\text { Using Moodle, } \\
\text { Blackboard, etc. }\end{array}$ & $1.3 \%$ & $6.8 \%$ & $5.5 \%$ & $51.6 \%$ & $\begin{array}{l}291.30^{*} \\
(\mathrm{n}=370)\end{array}$ & $\begin{array}{l}201.74^{*} \\
(\mathrm{n}=158)\end{array}$ \\
\hline $\begin{array}{l}\text { Accessing } \\
\text { Information about } \\
\text { Events, etc. }\end{array}$ & $1.8 \%$ & $4.5 \%$ & $16.8 \%$ & $44.5 \%$ & $\begin{array}{l}280.96^{*} \\
(n=321)\end{array}$ & $\begin{array}{l}221.53^{*} \\
(n=195)\end{array}$ \\
\hline $\begin{array}{l}\text { Student Scheduling } \\
\text { Appointments }\end{array}$ & $3.3 \%$ & $6.0 \%$ & $22.4 \%$ & $48.4 \%$ & $\begin{array}{l}251.76^{*} \\
(\mathrm{n}=296)\end{array}$ & $\begin{array}{l}207.84^{*} \\
(\mathrm{n}=174)\end{array}$ \\
\hline
\end{tabular}

* Mean ranks are statistically different for the two universities.

\subsection{Student Perceptions of Instructor Use of Technology}

According to the chi-square test results in Table 11 about students' perceptions regarding instructor use of technology, LSU and AIBU are significantly different on all of the items. Specifically, based on the students' perceptions, the US instructors at LSU use technology more effectively than the Turkish instructors at AIBU to support students' academic success.

Table 11. Instructor Use of Technology

\begin{tabular}{|c|c|c|c|c|}
\hline How many of your instructors... & & $\begin{array}{l}\text { LSU } \\
(n=399)\end{array}$ & $\begin{array}{l}\text { AIBU } \\
(n=384)\end{array}$ & Chi-Square \\
\hline $\begin{array}{l}\text { effectively use technology to support your academic } \\
\text { success? } \\
\text { provide you with adequate training for the technology } \\
\text { used in courses? } \\
\text { have adequate technical skills for carrying out course } \\
\text { instruction? } \\
\text { use the right kind(s) of technology. }\end{array}$ & $\begin{array}{l}\text { None } \\
\text { Some...All } \\
\text { None } \\
\text { Some...All } \\
\text { None } \\
\text { Some...All } \\
\text { None } \\
\text { Some...All }\end{array}$ & $\begin{array}{l}0.8 \% \\
99.2 \% \\
12.9 \% \\
87.1 \% \\
1.5 \% \\
98.5 \% \\
1.3 \% \\
98.7 \% \\
\end{array}$ & $\begin{array}{l}26.8 \% \\
73.2 \% \\
32.8 \% \\
66.9 \% \\
26.0 \% \\
74.0 \% \\
26.9 \% \\
72.8 \% \\
\end{array}$ & $\begin{array}{l}113.35^{*} \\
45.47^{*} \\
100.394^{*} \\
107.906^{*}\end{array}$ \\
\hline
\end{tabular}

${ }^{*}$ Chi-square values in boldface are statistically significant at the .05 level

In addition, the US instructors at LSU provide students with more adequate training for the technology used in courses 
than the Turkish instructors at AIBU. Furthermore, the US instructors at LSU have more adequate technical skills for carrying out course instruction than those of the Turkish instructors at AIBU. Moreover, the US instructors at LSU use the right kind(s) of technology in comparison to the Turkish instructors at AIBU.

\subsection{Perceived Importance of Training on Technology Use}

With the reference to the results in Table 12, being a better trainee at using technology to learn, study or complete coursework is more important for the Turkish students at AIBU in comparison to the US students at LSU.

Table 12. Importance of Getting Training on Use of Technology

\begin{tabular}{|c|c|c|}
\hline Question: & $\begin{array}{c}\text { LSU } \\
\text { (Mean Rank) }\end{array}$ & $\begin{array}{c}\text { AIBU } \\
\text { (Mean Rank) }\end{array}$ \\
\hline $\begin{array}{l}\text { How important is that you are of better trained or skilled at using technology } \\
\text { to learn, study or complete coursework? }\end{array}$ & $\begin{array}{l}346.13^{*} \\
(\mathrm{n}=399)\end{array}$ & $\begin{array}{l}428.70^{*} \\
(\mathrm{n}=372)\end{array}$ \\
\hline
\end{tabular}

* Mean ranks are statistically significant at the .05 level.

\subsection{Preferences of Students for Form of Instructor Communication}

The results in Table 13 show the students' preferences for form of their instructors' communication. The results with higher mean ranks indicate higher levels of preferences. Based on these findings, it can be stated that significantly higher numbers of US students at LSU than that of the Turkish students at AIBU prefer e-mail and LMS communication. However, significantly higher numbers of Turkish students at AIBU than that of the US students at LSU prefer forms of instructor communications including text messaging, instant messaging/online chatting, Twitter, Facebook, other social network sites, phone or phone-like sites over the Internet, face-to-face, and audio/video communications.

Table 13. Preferences for Form of Instructor Communication

\begin{tabular}{|c|c|c|}
\hline $\begin{array}{l}\text { Which forms of communication do you wish your instructors } \\
\text { used more ... less? }\end{array}$ & $\begin{array}{l}\text { LSU } \\
\text { (Mean Rank) }\end{array}$ & $\begin{array}{l}\text { AIBU } \\
\text { (Mean Rank) }\end{array}$ \\
\hline E-mail & $\begin{array}{l}412.93^{*} \\
(n=385)\end{array}$ & $\begin{array}{l}323.31^{*} \\
(\mathrm{n}=354)\end{array}$ \\
\hline Text Messaging & $\begin{array}{l}267.74^{*} \\
(\mathrm{n}=241)\end{array}$ & $\begin{array}{l}328.64^{*} \\
(\mathrm{n}=367)\end{array}$ \\
\hline Instant Messaging/Online Chatting & $\begin{array}{l}231.96^{*} \\
(\mathrm{n}=232)\end{array}$ & $\begin{array}{l}340.9^{*} \\
(\mathrm{n}=364)\end{array}$ \\
\hline Twitter & $\begin{array}{l}222.35^{*} \\
(\mathrm{n}=212)\end{array}$ & $\begin{array}{l}297.96^{*} \\
(\mathrm{n}=323)\end{array}$ \\
\hline Facebook & $\begin{array}{l}259.16 \\
(n=245)\end{array}$ & $\begin{array}{l}333.60 \\
(n=361)\end{array}$ \\
\hline Other Social Network Sites & $\begin{array}{l}201.95^{*} \\
(\mathrm{n}=194)\end{array}$ & $\begin{array}{l}301.51^{*} \\
(\mathrm{n}=335)\end{array}$ \\
\hline Social Studying Sites & $\begin{array}{l}267.79 \\
(n=270)\end{array}$ & $\begin{array}{l}265.16 \\
(n=264)\end{array}$ \\
\hline Phone or Phone-like sites over the Internet & $\begin{array}{l}225.36^{*} \\
(\mathrm{n}=238)\end{array}$ & $\begin{array}{l}329.34^{*} \\
(\mathrm{n}=333)\end{array}$ \\
\hline Face to Face & $\begin{array}{l}330.2^{*} \\
(\mathrm{n}=368)\end{array}$ & $\begin{array}{l}406.80^{*} \\
(\mathrm{n}=368)\end{array}$ \\
\hline Audio-Video Communications & $\begin{array}{l}250.97^{*} \\
(\mathrm{n}=261)\end{array}$ & $\begin{array}{l}332.40^{*} \\
(\mathrm{n}=331)\end{array}$ \\
\hline Course or Learning Management System (LMS) & $\begin{array}{l}361.80 \\
(\mathrm{n}=383)\end{array}$ & $\begin{array}{l}288.57^{*} \\
(\mathrm{n}=278)\end{array}$ \\
\hline
\end{tabular}

* Mean ranks are statistically significant at the .05 level

\section{Discussion and Conclusion}

The purpose of the study was to investigate differences and similarities between US students at LSU and Turkish students at AIBU in terms of technological device ownership by gender and year (i.e., freshmen, sophomore, junior, senior), uses of technology for academic course work, and perceived importance of technology to academic success. The findings revealed a significantly greater percentage of the US students reported technology ownership of most devices (i.e., laptop, smartphones, tablets) than the Turkish students as the students are compared both by gender and school year with the exception of desktop computers which have lower prices in general when compared to the laptop computers (Computer Hope, 2015). The differences in the device ownership between the US and Turkish students can be explained by the higher socio-economic level of the US students with \$53 thousand GDP per capita than the Turkish students with a \$11 thousand GDP per capita (Wikipedia, 2015; OECD, 2014) rather than cultural diversities.

Moreover, the findings of the study concerning the importance of resources and tools to academic success showed that an LMS, Web-based bibliography tools, and freely available course content beyond the campus are more important for 
the US students. However, academic institution's library website, e-portfolios, e-books, and simulations or educational games are more important for the Turkish students. In addition, similar results are found after the US and Turkish males and US and Turkish females are compared on the importance of resources and tools to academic success. In particular, the findings showed that LMS are more important for both US males and females at LSU in comparison to the Turkish males and females at AIBU. The differences concerning the importance of an LMS, and Web-based bibliography tools for academic success can be explained by the more common services provided for the US students at LSU in supporting the activities (e.g., accessing library resources, using an LMS such as Moodle, Blackboard) from a mobile device as indicated in Table 10.

In regard to the use of technology for academic course work in the past year, the findings indicated that there are significant differences in uses of most technological devices (i.e., e-portfolios, e-books, simulations and games) in favor of the US students in comparison to the Turkish students with the exception being course content from the Internet. Similarly, the comparison of US and Turkish males and US and Turkish females in uses of the technological devices for academic course work indicated notable differences mostly in favor of the US males and females except the course content from the Internet. These differences can be explained by the uses of right kinds of technology and more effective uses of technology to support students' academic success by the US instructors at LSU in comparison to the uses of technology by Turkish instructors at AIBU, based on the students' perceptions in Table 11. Moreover, as indicated in Table 11, other reasons behind more common uses of technology by the US students at LSU for academic course work in the past year could be more adequate technical skills of US instructors at LSU for carrying out course instruction than those of the Turkish instructors at AIBU, and more common support of US instructors at LSU of students by providing adequate training for the uses of technology in courses in comparison to the support of Turkish instructors at AIBU. Furthermore, the results concerning the importance of getting training on use of technology indicated that being a better trainee at using technology to learn, study or complete coursework are more important for the Turkish students at AIBU in comparison to the US students at LSU. The reason behind this result could be the perceived needs of the Turkish students receiving sufficient training on use of technology.

In addition, the findings of the study concerning the students' preferences for form of instructor communication indicated that greater numbers of US students at LSU than that of the Turkish students at AIBU prefer e-mail and LMS communication. However, notably higher numbers of Turkish students at AIBU prefer text messaging, instant messaging, social network sites (e.g., Facebook, Twitter), phone or phone-like sites over the Internet, face-to-face, and audio-video communications from their instructor. As previously discussed, the potential reason behind the preferences of US students for LMS form of instructor communication can be explained by the services provided for them at LSU in supporting the activities from a mobile device. Also, by considering the results about instructor use of technology in Table 11, it could be stated that uses of LMS communication are less common among the Turkish instructors at AIBU and that is why many Turkish students have become unfamiliar with LMS communication in educational environments. Therefore, it is more likely that the Turkish students prefer face-to-face communication and the other technological devices instead of an LMS for form of instructor communication.

As a result, according to the findings of this study in regard to the perceived importance of technology to academic success, although an LMS, Web-based bibliography tools, and freely available course content beyond their campus are more important for the US students at LSU, academic institution's library website, e-portfolios, e-books, and simulations or educational games are more important for the Turkish students at AIBU. However, the uses of technological devices (e.g., e-books, e-portfolios, simulations and games) for academic course work are more common among the US students in comparison to the Turkish students at AIBU. In addition, significantly higher numbers of US students at LSU than that of the Turkish students at AIBU prefer to use more professional technological systems such as LMS and e-mail for form of instructor communication. The more common uses of the technological systems and devices among the US students could be explained by their higher device ownership rates as a result of their higher socio-economic levels, the institution's support of technological activities (e.g., accessing library resources, using LMS, etc.) from technological devices particularly mobile ones (e.g., tablet, smartphone, etc.) and more common and effective uses of technological devices by the US instructors, based on the students' perceptions.

Myers and Tan (2002) discuss that awareness of cultural differences is quite substantial to achieve dissemination of information technology (IT) in various societies, however just cultural explanation in the uses of IT can be very simplistic. They suggest that researchers must move beyond the concept of national culture by having a research agenda that adopts a more dynamic view of the relationship between culture and global IT systems (Myers \& Tan, 2002). When we look beyond the cultural issues, the results of the study pointed to differences in device ownership and technology access largely as a function of local infrastructure and economic settings rather than cultural diversities between Turkey and the US.

The results of the study suggested a growing harmonization of processes of adaptation and use of technology among 
future generations. In regard to the Turkish students, the findings of this study suggest that they could be in need of receiving more effective training on the uses of technology that could improve academic course work. Moreover, the support of the institution for technological activities such as accessing library resources from technological devices could be increased and improved to augment the uses of technological devices for academic activities among the Turkish students. Furthermore, more effective uses of technological devices by the Turkish instructors could contribute to increased uses of technology for academic course work, and perceived importance of technology to academic success among the Turkish students at AIBU.

To conclude, the findings of this study suggest a further study to investigate and clarify why Turkish students mostly prefer technological devices or services such as social networking sites and instant messaging while the US students prefer more professional devices or services such as e-mail and an LMS for form of instructor communication. In addition, reasons behind why an academic institution's library website, e-portfolios, and simulations or educational games are more important for the Turkish students in comparison to the US students even while the uses of most of these technologies are more common among the US students can be investigated in another future study.

\section{References}

Ayçiçegi-Dinn, A., \& Caldwell-Harris, C. L. (2011). Individualism-collectivism among Americans, Turks and Turkish immigrants to the U.S. International Journal of Intercultural Relations, 35(1), 9-16. http://dx.doi.org/10.1016/j.ijintrel.2010.11.006

Blignaut, P., McDonald, T., \& Tolmie, J. (2002). The influence of experience, culture and spatial visualization ability on users' attitudes and anxiety towards computer use. In Human factors in information systems, edited by E. J. Szewczak, and C. R. Snodgrass, 269-280. Hershey, PA: IRM Press. http://dx.doi.org/10.4018/978-1-931777-10-0.ch019

Budde.com (2015). Turkey - Mobile Market - Overview and Statistics. http://www.budde.com.au/Research/Turkey-Mobile-Market-Overview-and-Statistics.html

Computer Hope (2015). Desktop computer vs. laptop computer. http://www.computerhope.com/issues/ch001399.htm

Delevi, R., \& Bugay, A. (2010). Understanding Change in Romantic Relationship Expectations of International Female Students from Turkey. Contemporary Family Therapy, 32(3), 257-272. http://dx.doi.org/10.1007/s10591-010-9124-4

Durndell, A., Haag, Z., \& Laithwaite, H. (2000). Computer self efficacy and gender: across cultural study of Scotland and Romania. Personality and Individual Differences, 28(6), 1037-1044. http://dx.doi.org/10.1016/S0191-8869(99)00155-5

Educause Center for Analytics and Research -ECAR (2013). ECAR student and faculty research. http://www.educause.edu/ecar

Haris, R., \& Davison, R. (2002). Anxiety and involvement: Cultural dimensions of attitudes toward computers in developing societies. In Global perspective of information technology management, edited by F. B. Tan, 234-258. Hershey, PA: Idea Group Publishing. http://dx.doi.org/10.4018/978-1-931777-11-7.ch017

Hurriyetdailynews.com (2015). Turks spend $\$ 13.3$ billion on telecommunications. http://www.hurriyetdailynews.com/turks-spend-133-billion-on-telecommunications----.aspx?pageID=238\&nID=80 $271 \&$ NewsCatID $=344$

Indalytics (2013). Education Technology in the US-Market Intelligence. http://indalytics.com/reports/education-technology-in-the-us-market-intelligence/_

Kolikant, Y. B. D. (2010). Digital natives, better learners? Students' beliefs about how the Internet influenced their ability to learn. Computers in Human Behavior, 26(6), 1384-1391. http://dx.doi.org/10.1016/j.chb.2010.04.012

Li, N., \& Kirkup, G. (2007). Gender and cultural differences in Internet use: A study of China and the UK. Computers \& Education, 48(2), 301-317. http://dx.doi.org/10.1016/j.compedu.2005.01.007

McCoy, S., Galletta, D., \& King, W. (2007). Applying TAM across cultures: the need for caution. European Journal of Information System, 16(1), 81-90. http://dx.doi.org/10.1057/palgrave.ejis.3000659

Myers, M. D., \& Tan, F. B. (2002). Beyond models of national culture in information system research. In Human factors in information systems, edited by E. J. Szewczak, and C. R. Snodgrass, 1-19. Hershey, PA: IRM Press. http://dx.doi.org/10.4018/978-1-931777-10-0.ch001

OECD (2014). OECD Science, Technology and Industry Outlook 2014. http://dx.doi.org/10.1787/sti_outlook-2014-en 
Oliver, B., \& Goerke, V. (2007). Australian undergraduates' use and ownership of emerging technologies: Implications and opportunities for creating engaging learning experiences for the Net Generation. Australasian Journal of Educational Technology, 23(2), 171-186. http://www.ascilite.org.au/ajet/ajet23/oliver.html

Singh, N., Fassott, G., Chao, M. C. H., \& Hoffmann, J. A. (2006). Understanding international Web site usage: A cross-national study of German, Brazilian, and Taiwanese online consumers. International Marketing Review, 23(1), 83-97. http://dx.doi.org/10.1108/02651330610646304

Teo, T., Su Luan, W., \& Sing, C. C. (2008). A cross-cultural examination of the intention to use technology between Singaporean and Malaysian pre-service teachers: an application of the Technology Acceptance Model (TAM). Educational Technology \& Society, 11(4), 265-280. http://www.ifets.info/journals/11_4/19.pdf

Wikipedia (2015b). Turkey. http://en.wikipedia.org/wiki/Turkey

Wikipedia (2014). Telecommunications in Turkey. http://en.wikipedia.org/wiki/Telecommunications_in_Turkey

Wikipedia (2015a). United States. Retrieved May 25, 2015, from http://en.wikipedia.org/wiki/ United States

Wikipedia (2015c). Louisiana State University. http://en.wikipedia.org/wiki/Louisiana_State_University_

Wikipedia (2015d). Abant Izzet Baysal University. http://en.wikipedia.org/wiki/Abant_Izzet_Baysal_University

\section{$(\mathrm{cc}) \mathrm{BY}$}

This work is licensed under a Creative Commons Attribution 3.0 License. 